Research article

\title{
EFFICACY OF PLANT-DERIVED FORMULATION “ARGUS RAS" IN Varroa destructor CONTROL
}

\author{
STANIMIROVIĆ Zoran ${ }^{1, a,}$, GLAVINIĆ Urošr ${ }^{1, a}$, LAKIĆ Nada $^{2}$, RADOVIĆ Dejan ${ }^{3}$, \\ RISTANIĆ Marko ${ }^{1}$, TARIĆ Elmin ${ }^{1}$, STEVANOVIĆ Jevrosima ${ }^{1}$
}

${ }^{1}$ Department of Biology, Faculty of Veterinary Medicine, University of Belgrade, Bul. Oslobodjenja 18, Belgrade, Serbia; ${ }^{2}$ Department of Statistics, Faculty of Agriculture, University of Belgrade, Nemanjina 6, Belgrade-Zemun, Serbia; ${ }^{3}$ Institute of Zoology, Faculty of Biology, University of Belgrade, Studentski $\operatorname{trg} 16$, Belgrade, Serbia

(Received 03 November 2016, Accepted 13 March 2017)

\begin{abstract}
Varroa destructor is the most important honey bee parasite. There are various methods used in the control of this mite, but none of them meets all requested criteria, to be safe, effective and easy to apply. The objective of this study was to evaluate the varroacidal efficacy of newly created plant-derived formulation Argus Ras (mixture of extracts of Sophora flavescens, Ginkgo biloba, Gleditsia chinensis and Teucrium chamaedrys) in a field trial. The investigation was conducted on 240 Apis mellifera colonies equalized in respect of brood amount, adult bee population and food reserves. Efficiency was evaluated by applying Argus Ras consecutively with two other acaricides, amitraz and oxalic acid. Average acaricidal efficacy of Argus Ras was $80.89 \%$, being higher of other previously tested essential oils. Besides, it showed a potential in knocking down the mites resistant to other acaricides. It should not be neglected that Argus Ras requires a smaller number of treatments and financial investments than other formulations used for the control of Varroa mites.
\end{abstract}

Keywords: Apis mellifera, Varroa destructor, plant-derived acaricide, oxalic acid, amitraz.

\section{INTRODUCTION}

European honey bee health is compromised by various pathogens, with ectoparasitic mite Varroa destructor being the greatest threat [1]. Varroa mite also acts as a vector and/ or activator of certain bee viruses [2,3] increasing their virulence and pathogenicity and seems to have a significant impact on honey bee immune response [4]. There is also a clue for a possible vector role of Varroa mites in the transmission of Nosema parasites. In recent losses of honey bee colonies recorded worldwide, $V$. destructor seems to play a substantial role [5].

\footnotetext{
*Corresponding author: e-mail: zoran@vet.bg.ac.rs
}

${ }^{a}$ These authors contributed equally to the manuscript 
There are various available methods, techniques and acaricides used in the control of $V$. destructor, but none of them meets all requested criteria, to be safe, effective and easy to apply [1]. Substances used for mite control are usually classified in two groups: synthetic ("hard") and natural ("soft") acaricides [1]. Synthetic acaricides such as coumaphos (organophosphate), tau-fluvalinate, flumethrine (pyrethroid) and amitraz (formamidine) were widely used in the last decades with variable efficacy. Their residues accumulate inside the hive and could exhibit negative effects on bees and brood [6] and contaminate their products [7] with potential health risk to consumers [8,9]. Moreover, due to the repeated use of these substances, mite populations develop resistance to pyrethroids (fluvalinate and flumethrin), but also to coumaphos and, in less extent, to amitraz [10-12]. Increased Varroa resistance to synthetic acaricides necessitated the introduction of natural substances with acaricidal effects, such as organic acids (oxalic, formic, lactic) and essential oils (thymol, menthol, camphor, eucaliptol etc.). The advantages of these natural compounds are a lower risk of pollution of hive products $[13,14]$ and lower probability of inducing mite resistance after repeated treatments. However, their efficacy is highly dependent on climate, in-hive conditions and application technique, therefore often inconsistent and more variable compared to the effects of synthetic acaricides (reviewed in 1).

Argus Ras is a registered dietary supplement based on extracts of four plants (Sophora flavescens, Ginkgo biloba, Gleditsia chinensis and Teucrium chamaedrys) and contains flavonoides, terpenoides and tannins as active substances. According to indications of the producer (MATEX, Šabac, Serbia), Argus Ras disturbs and obstructs development and survival of Varroa mites in both reproductive and phoretic phases. The objective of our study was to evaluate varroacidal efficacy of Argus Ras when applied consecutively with two commonly used acaricidal substances, amitraz and oxalic acid.

\section{MATERIAL AND METHODS}

\section{Honey bee colonies}

The investigation was conducted on 240 Apis mellifera colonies in a standard twobody Langstroth hives. The colonies were located in the Belgrade region, Serbia $\left(44^{\circ} 41^{\prime} 35^{\prime}\right.$ N, $20^{\circ} 33^{\prime} 12^{\prime}$ E). Experimental colonies were equalized in respect of brood size, adult bee population and amount of stored food [15]. After equalization, colonies were divided into three groups (Table 1) each consisted of 80 colonies. During the experimental period, colonies were regularly checked for bee and brood pathology by a veterinary specialist following methods described in the Manual of Diagnostic Tests and Vaccines for Terrestrial Animals published by the Office International des Epizooties (OIE 2013) and, except Varroa mites, no clinical signs of any bee disease were noticed. Colonies were also carefully monitored to notice any adverse effect of tested substance on colony members, development and performance. 
Table 1. Experimental design

\begin{tabular}{cccc}
\hline \multirow{2}{*}{ Group } & \multicolumn{3}{c}{ Treatments } \\
\cline { 2 - 4 } & $\mathbf{0 1 - 2 0 . ~ S e p t e m b e r}$ & 21. September-11. October & 17. November \\
\hline A & Argus Ras & - & Oxalic acid \\
B & Amitraz & - & Oxalic acid \\
C & Argus Ras & Amitraz & Oxalic acid \\
\hline
\end{tabular}

\section{Treatments}

Argus Ras was provided by MATEX, Šabac, Serbia, whilst Amitraz and Oxalic Acid were purchased from Sigma-Aldrich (St. Louis, MO). Effect of Argus Ras on Varroa mite fall was tested and compared with the effects of two widely used acaricidal substances: amitraz (hard acaricide) and oxalic acid (soft acaricide). The Argus Ras (Certificate No. 01-161) was applied following producer's recommendation: one strip was inserted in the center of each hive body for a 20 -days period. Amitraz (CAS No.: 33089-61-1) was applied by fumigation using three drops of $12.5 \%$ solution per colony [16], five times at 4-days intervals. Oxalic acid (CAS No.: 144-62-7) was applied in a form of $3.2 \%$ dehydrate solution by trickling the bees in the spaces between combs [17] in broodless period ( $5 \mathrm{ml}$ per bee space).

The efficacy of each applied substance was estimated over its contribution in knockingdown of Varroa mites. For that purpose we used anti-varroa bottom boards with a white metal sampling sheet covered with neutral oil (to prevent reattachment of fallen mites to the bees and possible predators (ants and other scavengers) to exterminate dead mites [18]. Fallen mites were sampled every 2 days during the treatment period. The number of fallen mites was counted and recorded after each treatment and the sum of those numbers calculated after the last treatment for each group (A, B and C) was designated as total mite fall. Then, the proportion (in \%) of mites fell after each treatment in total mite fall was estimated.

All three groups (Table 1) had the same treatment period (the first and the last treatment were done in the same period). Treatment with Oxalic acid was the last in all three groups. This acid is considered a highly efficient acaricide with up to $99 \%$ efficacy in the broodless period and therefore adequate to be used as final control treatment for the evaluation of varroacide efficacy of previously applied treatments [19].

The results obtained in group $\mathrm{C}$ were also used for the evaluation of Argus Ras efficacy using Amitraz as follow-up treatment according to the formula recommended by the European Medicines Agency - EMA [20]. This method was not applied for Oxalic acid efficacy evaluation because the time distance between treatments allows for the possibility of reinfestation with Varroa mites. 


\section{Statistical analysis}

The obtained data was carried out using software STATISTICA v. 7 (StatSoft, Inc., Tulsa, OK, USA). Due to the data characteristics, the results were presented through the median, interval of variation and interquartile differences. Differences between median effectiveness of treatments were tested using Kruskal-Wallis test and MannWhitney U test.

\section{RESULTS}

The treatment with Argus Ras in group A resulted in median mite drop of $81.89 \%$ (76.73-86.81\%) of total number of mites that dropped during both treatments. Oxalic acid treatment as second treatment induced drop of remaining 18.11\% (13.19-23.27\%) mites in group A (Table 2).

Table 2. Contribution of each acaricidal treatment in $\%$ in total mite fall

\begin{tabular}{clcccrrr}
\hline Group & $\begin{array}{l}\text { Acaricide } \\
\text { treatment }\end{array}$ & $\begin{array}{c}\text { No. of } \\
\text { colonies }\end{array}$ & Median & Min. & Max. & $\begin{array}{c}\text { Lower } \\
\text { quart }\end{array}$ & $\begin{array}{c}\text { Upper } \\
\text { quart }\end{array}$ \\
\hline \multirow{2}{*}{ A } & Argus Ras & 80 & 81.89 & 76.73 & 86.81 & 80.15 & 83.92 \\
& Oxalic acid & 80 & 18.11 & 13.19 & 23.27 & 16.08 & 19.84 \\
\multirow{2}{*}{ B } & Amitraz & 80 & 95.91 & 91.71 & 98.14 & 95.02 & 96.60 \\
& Oxalic acid & 80 & 4.09 & 1.86 & 8.29 & 3.40 & 4.98 \\
& Argus Ras & 80 & 77.40 & 73.89 & 88.19 & 75.48 & 83.44 \\
C & Amitraz & 80 & 21.38 & 11.39 & 24.78 & 16.11 & 23.54 \\
& Oxalic acid & 80 & 1.22 & 0.39 & 1.47 & 0.43 & 1.41 \\
\hline
\end{tabular}

In group B, the treatment with Amitraz caused median mite drop of 95.91\% (91.71$98.14 \%$ ), whilst subsequent treatment with Oxalic acid induced drop of the remaining 4.09\% (1.86-8.29\%) mites (Table 2).

Applied treatments in group C manifested following acaricidal efficiency: Argus Ras (first treatment) had induced median fall of $77.40 \%(73.89-88.19 \%)$ mites, Amitraz (second treatment) $21.38 \%(11.39-24.78 \%)$ mites, and Oxalic acid (third treatment) $1.22 \%(0.39 \%-1.47 \%)$ (Table 2$)$.

According to the results of Mann-Whitney $U$ test, the acaricidal effects of Argus Ras significantly $(\mathrm{z}=3.549 ; \mathrm{p}<0.001)$ differ between group A and C (Figure 1), with average acaricidal efficacy of $80.89 \%$.

The results of Kruskal-Wallis test revealed that the efficiency of Oxalic acid between the three groups was significantly $(\mathrm{H}=212.468$; $\mathrm{p}<0.001)$ different. Mann-Whitney $\mathrm{U}$ test showed significantly higher efficiency of Oxalic acid in group A compared to group $B(z=10.921, p<0.001)$ and group $C(z=10.922, p<0.001)$. The efficiency of this 
acid was also significantly higher $(\mathrm{z}=10.922, \mathrm{p}<0.001)$ in group $\mathrm{B}$ compared to group C (Figure 2).
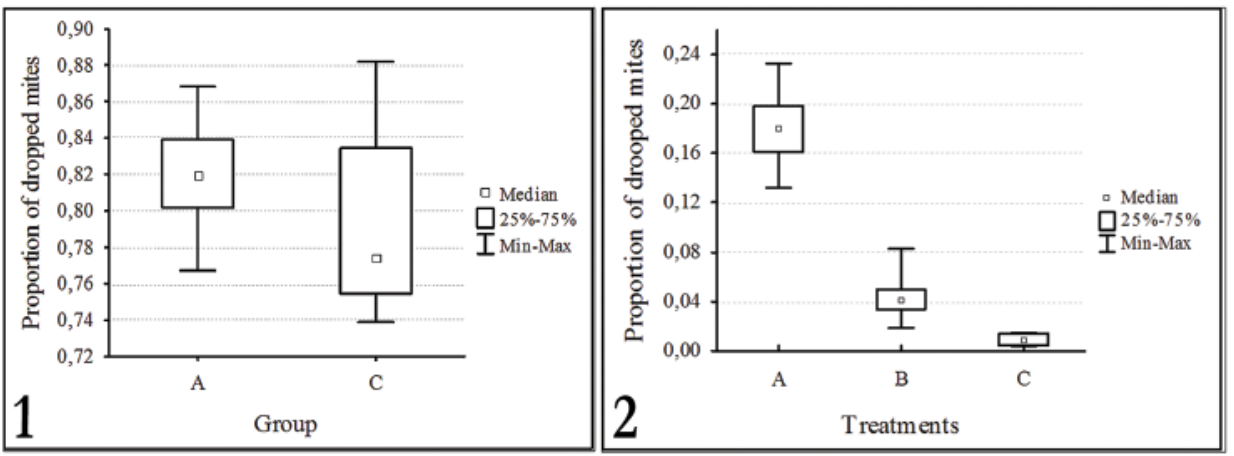

Figure 1. Acaricidal efficacy of Argus Ras in groups A and C

Figure 2. Acaricidal efficacy of Oxalic acid on remained mites in all treated groups (A, B and C)

Treatment with Amitraz in group Cinduced median drop of $21.3 \%$ mites (that represent $96.00 \%$ of mites remaining after treatment with Argus Ras), while in group B (when applied as first treatment) caused median mite drop of $95.91 \%$ (Figure 3). Results of Mann-Whitney $U$ test $(z=-0.630 ; p=0.529)$ revealed no significant differences in acaricidal effects of Amitraz between groups B and C.
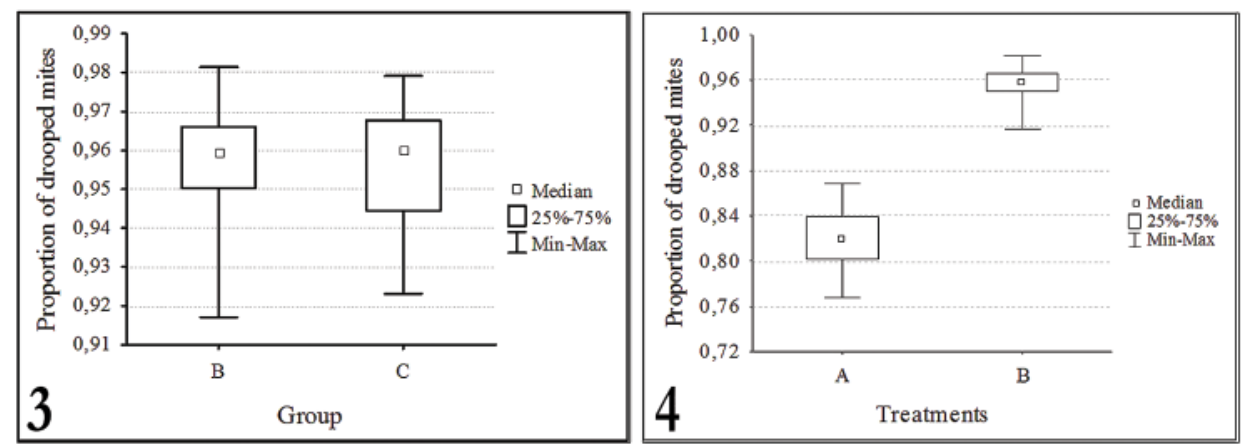

Figure 3. Acaricidal efficacy of Amitraz in group B (when applied as first treatment) and in group $\mathrm{C}$ (on mites remained after treatment with Argus Ras)

Figure 4. Effectiveness of Argus Ras (in group A) and Amitraz (in group B)

Acaricidal efficacy of Argus Ras in group A was significantly lower ( $\mathrm{z}=10.921$, $\mathrm{p}<0.001)$ than efficiency of Amitraz in group B.

In group C, Argus Ras induced average fall of 175.55 mites, while Amitraz, used as follow-up treatment, knocked-down on average 42.28 residual mites. Thus, the treatment efficacy of Argus Ras, estimated according to the formula recommended by EMA (\% mite reduction), was $80.59 \%$. Importantly, treatments with Argus Ras did not affect adversely on brood, adult bee population and colony performance. 


\section{DISCUSSION}

Considering the extent of damage $V$. destructor inflicts on European honey bee colonies worldwide, the control of this parasite is one of the most important tasks in beekeeping practice. Despite numerous available means and methods of confirmed or anecdotal efficacy, reliable long term solution for this problem is not yet available. Therefore, there is a great need for investigating and improving the ways of Varroa mite infestation control. Testing new substances and products with acaricidal effects may help to address this issue.

With the raise of public awareness of the risks of pesticide overuse and contamination of environment and food, there is a worldwide growing interest in organic agriculture, especially in highly developed countries. In organic beekeeping, there are special requirements regarding pest control and only few Varroa control methods and substances are considered acceptable. Beside biotechnological measures believed to be able to reduce Varroa infestation levels to some extent, methods such as sugar dusting and appliance of natural substances (essential oils and organic acids) are acceptable in organic beekeeping [21]. Argus Ras is an entirely plant-derived product and as such is suitable for both organic and conventional beekeeping.

The results of this study show that Argus Ras has an average efficacy of $80.89 \%$, and $80.59 \%$ when calculated according to the formula recommended by EMA [20]. This acaricidal efficacy is rather high, especially in comparison with other previously tested essential oils such as garlic, turmetic, tulsi, ajwin, cinnamon and clove oils, whose effectiveness ranged from 65.00 to $77.54 \%$ [22] or jasmine, black cumin and neem oils which showed effectiveness from 24 to 35\% [23]. Effect of Argus Ras in this study $(80.89 \%)$ was significantly lower $(z=10.921, \mathrm{p}<0.001)$ (Figure 4) than the effect observed with Amitraz (95.72\%). Nevertheless, there is a huge difference between soft and hard acaricides regarding environmental and other risks. It is known that plant-derived soft acaricides have a very low potential of honey bee intoxication in contrast to other acaricides that were reported to exert toxic effects on bees, as in the case of amitraz [24], coumaphos [25], fluvalinate [26], formic acid [27] and oxalic acid [17]. Besides, plant-derived soft acaricides do not contaminate hive products, opposed to other acaricides that have been proven to leave residues: oxalic and formic acid [14] fluvalinate and coumaphos, amitraz and chlorfenvinphos [28] and pose risk to consumers of bee products $[8,9]$.

Given that plant-derived soft acaricides pose low or no risk to the environment, honey bees and bee products, it can be expected that Argus Ras has similar properties, although this has to be experimentally confirmed. In addition, it requires a smaller number of treatments and financial investments than other formulations used for Varroa control.

In this study, Oxalic acid exerted the lowest acaricidal effect in group C (Figure 2). This could be explained with preceding effects of Amitraz and Argus Ras. However, 
as no significant differences were found in effects of Amitraz between groups B and $\mathrm{C}$ (Figure 3), the higher proportion of mites knocked down in group $\mathrm{C}$ before the treatment with Oxalic acid could be attributed to the acaricidal effect of Argus Ras. This could be explained by acaricidal effects of Argus Ras on amitraz-resistant mites, even more so as there are reports on Varroa resistance to amitraz especially in regions where it is often used [29].

No adverse effects of Argus Ras were recorded neither on brood and adult bee=health, nor on the development and productivity of the treated colonies. As for other plantderived formulations, health-promoting effects of Argus Ras could be expected. Further investigations are needed to evaluate the potential of Argus Ras to enhance the immunity of bees and help them to cope with microsporidial and other pathogens.

Argus Ras possesses rather high efficacy in comparison with other previously tested natural-based products. As entirely plant-derived product, Argus Ras is suitable for both organic and conventional beekeeping similar to alternative herbal treatments against nosemosis. Compared to other formulations used for Varroa control, this product has additional advantages as it requires less number of treatments and financial investments. Finally, no adverse effects of Argus Ras were recorded neither on brood or adult bees, nor on the development and productivity of the colonies.

\section{Acknowledgements}

This research was supported by the Ministry of Education, Science and Technological Development of the Republic of Serbia, Grant No III46002, led by Professor Zoran Stanimirovic.

\section{Authors' contributions}

SZ conceived and designed the study and made substantial contribution to acquisition, analysis and interpretation of data and also gave final approval of the version to be published. GU participated in designing of the study, coordinated experiment performance, made substantial contributions to interpretation of data and drafted the manuscript. LN performed the statistical analysis and made substantial contributions to inerpretation of data. SJ and RD have been involved in manuscript writing and its critical revising. TE and RM carried out the experiment and participated in manuscript writing. All authors read and approved the final manuscript.

\section{Declaration of conflicting interests}

The author(s) declared no potential conflicts of interest with respect to the research, authorship, and/or publication of this article. 


\section{REFERENCES}

1. Rosenkranz P, Aumeier P, Ziegelmann B: Biology and control of Varroa destructor. J Invertebr Pathol 2010, 103:S96-S119.

2. Gisder S, Aumeier P, Genersch E: Deformed wing virus: replication and viral load in mites (Varroa destructor). J Gen Virol 2009, 90:463-467

3. Simeunovic P, Stevanovic J, Cirkovic D, Radojicic S, Lakic N, Stanisic LJ, Stanimirovic Z: Nosema ceranae and queen age influence the reproduction and productivity of the honey bee colony. J Apicult Res 2014, 53:545-554.

4. Yang X, Cox-Foster DL: Impact of an ectoparasite on the immunity and pathology of an invertebrate: evidence for host immunosuppression and viral amplification. P Natl Acad Sci USA 2005, 102:7470-7475.

5. Goulson D, Nicholls E, Botías C, Rotheray EL: Bee declines driven by combined stress from parasites, pesticides, and lack of flowers. Science 2015, 347:1255957.

6. Mullin CA, Frazier M, Frazier JL, Ashcraft S, Simonds R, Pettis JS: High levels of miticides and agrochemicals in North American apiaries: implications for honey bee health. PLoS One 2010, 5:e9754.

7. Wallner K: Varroacides and their residues in bee products. Apidologie 1999, 30:235-248.

8. Stanimirovic Z, Stevanovic J, Jovanovic S, Andjelkovic M: Evaluation of genotoxic effects of Apitol ${ }^{\circledR}$ (cymiazole hydrochloride) in vitro by measurement of sister chromatid exchange. Mutat Res-Gen Tox En 2005, 588:152-157.

9. Radakovic M, Stevanovic J, Djelic N, Lakic N, Knezevic-Vukcevic J, Vukovic-Gacic B, Stanimirovic Z: Evaluation of the DNA damaging effects of amitraz on human lymphocytes in the Comet assay. J Biosciences 2013, 38:53-62.

10. Milani N: The resistance of Varroa jacobsoni Oud. Apidologie 1999, 30:229-234.

11. Thompson HM, Brown MA, Ball RF, Bew MH: First report of Varroa destructor resistance to pyrethroids in the UK. Apidologie 2002, 33:357-366.

12. Kanga LH, Adamczyk J, Marshall K, Cox R: Monitoring for resistance to organophosphorus and pyrethroid insecticides in Varroa mite populations. J Econ Entomol 2010, 103:17971802.

13. Floris I, Satta A, Cabras P, Garau VL, Angioni A: Comparison between two thymol formulations in the control of Varroa destructor: effectiveness, persistence, and residues. J Econ Entomol 2004, 97:187-191.

14. Bogdanov S: Contaminants of bee products. Apidologie 2006, 37:1-18.

15. Delaplane KS, Van Der Steen J, Guzman-Novoa E: Standard methods for estimating strength parameters of Apis mellifera colonies. J Apicult Res 2013, 52:1-12.

16. Gregorc A, Planinc I: Use of thymol formulations, amitraz, and oxalic acid for the control of the Varroa mite in honey bee (Apis mellifera carnica) colonies. J Apic Sci 2012, 56:61-69.

17. Nanetti A, Buchler R, Charriere JD, Fires I, Helland S, Imdorf A, Korpela S, Kristiansen P: Oxalic acid treatments for Varroa control (review). Apiacta 2003, 38:81-87.

18. Rosenkranz P, Fries I, Boecking O, Stürmer M: Damaged Varroa mites in the debris of honey bee (Apis mellifera L) colonies with and without hatching brood. Apidologie 1997, 28:427-437.

19. Gregorc A, Planinc I: Using oxalic acid for Varroa mite control in honeybee colonies during the beekeeping season. Slov Vet Res 2004, 41:35-39. 
20. EMA - European Medicines Agency, EMA/CVMP/EWP/459883/2008, Committee for Medicinal Products for Veterinary Use (CVMP), Guideline on veterinary medicinal products controlling Varroa destructor parasitosis in bees. http:/ /www.ema.europa.eu/docs/ en_GB/document_library/Scientific_guideline/2010/11/WC500099137.pdf

21. Stevanovic J, Stanimirovic Z, Lakic N, Djelic N, Radovic I: Stimulating effect of sugar dusting on honey bee grooming behaviour. Entomol Exp Appl 2012, 143:23-30.

22. Goswami V, Srivastava P, Khan MS: Efficacy of essential oils against Varroa destructor infesting Apis mellifera Linn. colonies and their impact on brood development. J Appl Nat Sci 2014, 6:27-30.

23. Allam SFM, Hassan MF, Risk MA, Zaki AU, Papierok B: Utilization of essential oils and chemical substances alone or in combination against Varroa mite (Varroa destructor), a parasite of honeybees. Iobc Wprs Bulletin 2003, 26:273-278.

24. Hillier NK, Frost EH, Shutler D: Fate of dermally applied miticides fluvalinate and amitraz within honey bee (Hymenoptera: Apidae) bodies. J Econ Entomol 2013, 106:558-565.

25. Gregorc A: A clinical case of honey bee intoxication after using coumaphos strips against Varroa destructor. J Apicult Res 2012, 51:142-143.

26. Frost EH, Shutler D, Hillier NK: Effects of fluvalinate on honey bee learning, memory, responsiveness to sucrose, and survival. J Exp Biol 2013, 216:2931-2938.

27. Underwood RM, Currie RW: Effect of concentration and exposure time on treatment efficacy against Varroa mites (Acari: Varroidae) during indoor winter fumigation of honey bees (Hymenoptera: Apidae) with formic acid. J Econ Entomol 2005, 98:1802-1809.

28. Lodesani M, Costa C, Serra G, Colombo R, Sabatini AG: Acaricide residues in beeswax after conversion to organic beekeeping methods. Apidologie 2008, 39:324-333.

29. Maggi MD, Ruffinengo SR, Negri P, Eguaras MJ: Resistance phenomena to amitraz from populations of the ectoparasitic mite Varroa destructor of Argentina. J Parasitol Res 2010, 107:1189-1192.

\title{
EFIKASNOST KOMBINACIJE BILJNIH EKSTRAKATA “ARGUS RAS” U KONTROLI Varroa destructor
}

\author{
STANIMIROVIĆ Zoran, GLAVINIĆ Uroš, LAKIĆ Nada, RADOVIĆ Dejan, \\ RISTANIĆ Marko, TARIĆ Elmin, STEVANOVIĆ Jevrosima
}

Varroa destructor je najznačajniji parazit medonosne pčele. Razne metode se koriste za kontrolu ovog krpelja, ali nijedna od njih ne ispunjava sve potrebne kriterijume: da bude bezbedna, efikasna i jednostavna za primenu. Cilj ovog rada bio je da se ispita varoacidna efikasnost nove formulacije na bazi biljaka, preparata Argus Ras (mešavina ekstrakata Sophora flavescens, Ginkgo biloba, Gleditsia chinensis i Teucrium chamaedrys) u terenskom eksperimentu. Ispitivanje je obavljeno na 240 društava Apis mellifera ujednačenih po količini legla, brojnosti adultnih pčela i rezervama hrane. Efikasnost je procenjivana primenom preparata Argus Ras u kombinaciji sa druga dva akaricida, amitrazom i ok- 
salnom kiselinom. Prosečna akaricidna efikasnost preparata Argus Ras bila je 80,89\%, što je više od efikasnosti ranije ispitivanih etarskih ulja. Osim toga, ispitivani preparat je pokazao potencijal u obaranju Varroa krpelja rezistentnih na druge akaricide. $\mathrm{Ne}$ treba zanemariti ni to što Argus Ras zahteva manji broj tretmana i finansijskih ulaganja nego druge formulacije koje se koriste za kontrolu Varroa krpelja. 